\title{
Gramella marina sp. nov., isolated from the sea urchin Strongylocentrotus intermedius
}

\author{
Olga I. Nedashkovskaya, ${ }^{1}$ Seung Bum $\mathrm{Kim}^{2}$ and Kyung Sook Bae ${ }^{3}$
}

Correspondence

Olga I. Nedashkovskaya

olganedashkovska@piboc.dvo.ru or olganedashkovska@gmail.com

\author{
${ }^{1}$ Pacific Institute of Bioorganic Chemistry of the Far-Eastern Branch of the Russian Academy of \\ Sciences, Prospekt 100 Let Vladivostoku 159, 690022, Vladivostok, Russia \\ ${ }^{2}$ Department of Microbiology, College of Bioscience and Biotechnology, Chungnam National \\ University, 220 Gung-dong, Yuseong, Daejeon 305-764, Republic of Korea \\ ${ }^{3}$ Biological Resources Center, Korea Institute of Bioscience and Biotechnology, 52 Oun-dong, \\ Yuseong, Daejeon 305-333, Republic of Korea
}

\begin{abstract}
The taxonomic position of a novel Gram-stain-negative, aerobic, heterotrophic, gliding, yelloworange-pigmented bacterium, isolated from the sea urchin Strongylocentrotus intermedius and designated strain KMM $6048^{\top}$, was established. Phylogenetic analysis based on $16 \mathrm{~S}$ rRNA gene sequencing revealed that the isolate was a member of the family Flavobacteriaceae affiliated with recognized species of the genus Gramella, forming a distinct lineage within the genus. 16S rRNA gene sequence similarities between strain $\mathrm{KMM} 6048^{\top}$ and the type strains of species of the genus Gramella were 97.4-98.4\%. In line with representative members of the genus Gramella, strain $\mathrm{KMM} 6048^{\top}$ was oxidase- and catalase-positive, hydrolysed gelatin and starch, utilized carbohydrates and possessed a DNA G $+\mathrm{C}$ content of $40.0 \mathrm{~mol} \%$. However, differentiating phenotypic traits and phylogenetic distinctiveness clearly indicated that the strain represented a novel species within the genus Gramella, for which the name Gramella marina sp. nov. is

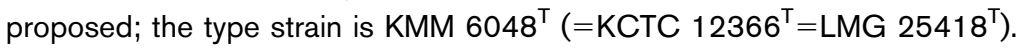

The genus Gramella, a member of the family Flavobacteriaceae (phylum 'Bacteroidetes'), and the species Gramella echinicola were created to accommodate a gliding, strictly aerobic, yellow-orange-pigmented, Gram-stainnegative, and oxidase- and catalase-positive bacterial strain associated with the sea urchin Strongylocentrotus intermedius from the Gulf of Peter the Great (Nedashkovskaya et al., 2005). A further species in the genus, Gramella portivictoriae, isolated from a sediment sample from the South China Sea (Lau et al., 2005), was subsequently described.

In this work, a novel strain, designated KMM $6048^{\mathrm{T}}$, was isolated and identified using a polyphasic approach. As shown by phylogenetic analysis, strain KMM $6048^{\mathrm{T}}$ belonged to the family Flavobacteriaceae, phylum 'Bacteroidetes', and formed a distinct lineage within the genus Gramella. On the basis of phenotypic and molecular phylogenetic evidence, the isolate represents a novel species of the genus Gramella.

Strain KMM $6048^{\mathrm{T}}$ was isolated from a sea urchin, Strongylocentrotus intermedius, collected at a depth of $3 \mathrm{~m}$ in Troitsa Bay, Gulf of Peter the Great, Sea of Japan (also known as the East Sea), Pacific Ocean, in September 2002. For strain isolation, $0.1 \mathrm{ml}$ sea-urchin tissue homogenate

The GenBank/EMBL/DDBJ accession number for the 16S rRNA gene sequence of Gramella marina KMM $6048^{\top}$ is AY753911. was plated onto marine agar 2216 (Difco). After primary isolation and purification, the strain was cultivated at $28{ }^{\circ} \mathrm{C}$ on the same medium and stored at $-80^{\circ} \mathrm{C}$ in marine broth (Difco) supplemented with $20 \%(\mathrm{v} / \mathrm{v})$ glycerol.

DNA extraction, PCRs and sequencing of the 16S rRNA gene were carried out as described previously (Kim et al., 1998). The sequence obtained (1438 bp) was aligned with those of representative members of selected genera of the family Flavobacteriaceae by using PHYDIT version 3.2 (http://plaza.snu.ac.kr/ jchun/phydit/). Phylogenetic trees were inferred by using suitable programs of the PHYLIP package (Felsenstein, 1993). Phylogenetic distances were calculated from the Jukes-Cantor model (Jukes \& Cantor, 1969) and trees were constructed on the basis of the neighbour-joining (Saitou \& Nei, 1987) and maximumlikelihood (Felsenstein, 1993) algorithms. A bootstrap analysis was performed with 1000 resampled datasets by using the SEQBOOT and CONSENSE programs of the PHYLIP package.

Phylogenetic analysis based on 16S rRNA gene sequences revealed that strain $\mathrm{KMM} 6048^{\mathrm{T}}$ was a member of the family Flavobacteriaceae and formed a coherent cluster with species of the genus Gramella (Fig. 1). The 16S rRNA gene sequence similarities between the isolate and the type strains of G. echinicola and G. portivictoriae were 97.5 and $98.4 \%$, respectively. According to Stackebrandt \& Ebers 


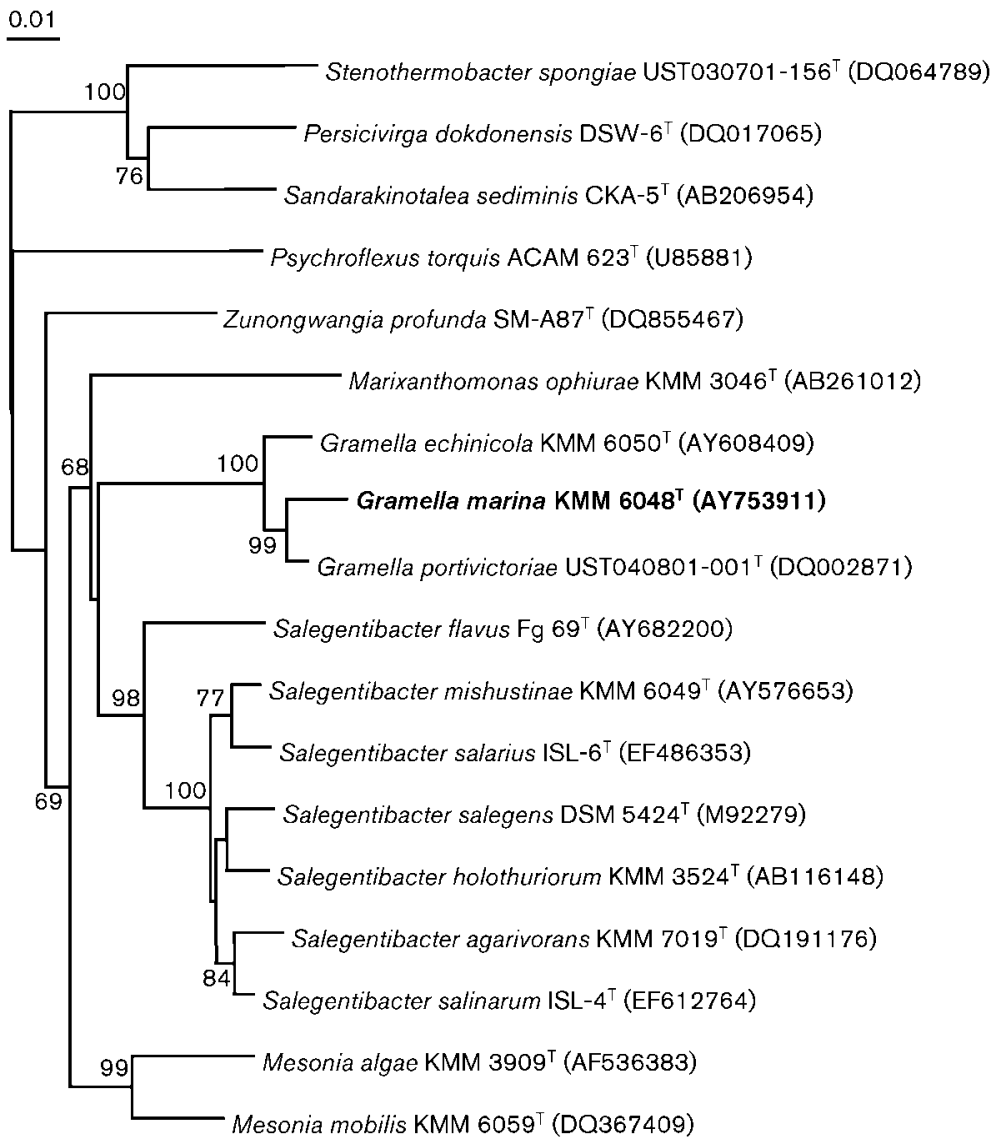

Fig. 1. Neighbour-joining phylogenetic tree based on the 16S rRNA gene sequences of $\mathrm{KMM} 6048^{\top}$ and related members of the family Flavobacteriaceae. The same tree topology was recovered using the maximum-likelihood algorithm. Numbers at nodes are the levels of bootstrap support (\%) from 1000 resampled datasets. Stenothermobacter spongiae UST030701-156 ${ }^{\top}$ (DQ064789), Persicivirga dokdonensis DSW-6 ${ }^{\top}$ (D0017065) and Sandarakinotalea sediminis CKA $-5^{\top}$ (AB206954) were used as the outgroups. Bar, 0.01 substitutions per nucleotide position.

(2006), DNA-DNA reassociation experiments between two bacterial strains are required to demonstrate whether or not they belong to the same species only when they share more than 98.7-99.0\% 16S rRNA gene sequence similarity. For this reason, DNA-DNA hybridization experiments were not performed.

DNA was isolated following the method of Marmur (1961) and its $\mathrm{G}+\mathrm{C}$ content was determined by the thermal denaturation method (Marmur \& Doty, 1962). The DNA $\mathrm{G}+\mathrm{C}$ content of strain $\mathrm{KMM} 6048^{\mathrm{T}}$ was $40.0 \mathrm{~mol} \%$, a value similar to those reported for the two other recognized species of the genus Gramella (Lau et al., 2005; Nedashkovskaya et al., 2005).

Analysis of fatty acid methyl esters was performed according to the standard protocol of the Microbial Identification System (Microbial ID). Strain KMM $6048^{\mathrm{T}}$ was cultivated on marine agar $2216 \mathrm{E}$ at $25{ }^{\circ} \mathrm{C}$ for $48 \mathrm{~h}$. The fatty acids of strain KMM $6048^{\mathrm{T}}$ accounting for greater than $5 \%$ of the total fatty acids were: iso- $\mathrm{C}_{15: 0}, 17.9 \%$; iso$\mathrm{C}_{17: 0} 3-\mathrm{OH}, 12.4 \%$; summed feature $3\left(\mathrm{C}_{16: 1} \omega 7 c\right.$ and/or iso- $\mathrm{C}_{15: 0} 2-\mathrm{OH}$ fatty acids), $11.6 \%$; anteiso- $\mathrm{C}_{15: 0}, 8.6 \%$; iso- $\mathrm{C}_{16: 0}, 6.3 \%$; iso- $\mathrm{C}_{17: 1} \omega 9 c, 5.5 \%$; and $\mathrm{C}_{17: 0} 2-\mathrm{OH}$, $5.1 \%$. The fatty acid profile of the novel isolate was similar to those of recognized species of the genus Gramella (Lau et al., 2005; Nedashkovskaya et al., 2005), but it differed from them in the proportions of iso- $\mathrm{C}_{16: 0}$, iso- $\mathrm{C}_{15: 0} 3-\mathrm{OH}$ and $\mathrm{C}_{17: 0}$ 2-OH (Table 1). Also, $\mathrm{C}_{15: 0}$, iso- $\mathrm{C}_{15: 1} \mathrm{G}$, iso$\mathrm{C}_{16: 1} \mathrm{G}$ and anteiso- $\mathrm{C}_{17: 1} \omega 9 c$ were detected only in cells of strains KMM $6048^{\mathrm{T}}$ and G. echinicola $\mathrm{KMM} 6050^{\mathrm{T}}$, whereas $\mathrm{C}_{15: 0} 3-\mathrm{OH}$ was found only in cells of $G$. portivictoriae UST040801-001 ${ }^{\mathrm{T}}$; however, these differences may be a result of different cultivation conditions. Isoprenoid quinones were extracted and analysed using a standard procedure (Minnikin et al., 1984). The major respiratory quinone of strain KMM $6048^{\mathrm{T}}$ was MK-6, which was in line with that of the two recognized species of the genus Gramella and all other members of the family Flavobacteriaceae (Bernardet et al., 2002; Lau et al., 2005; Nedashkovskaya et al., 2005).

Phenotypic analysis of strain KMM $6048^{\mathrm{T}}$ was performed by using previously described methods (Nedashkovskaya et al., 2003a, b). In addition, API 20E, API 20NE and API ZYM galleries (bioMérieux) and GN2 MicroPlates (Biolog) were used according to the manufacturers' instructions, except that the galleries were incubated at $28{ }^{\circ} \mathrm{C}$. Susceptibility to antibiotics was tested using the diffusion method with discs containing ampicillin $(10 \mu \mathrm{g})$, benzylpenicillin (10 $\mathrm{U})$, carbenicillin $(100 \mu \mathrm{g})$, cefalexin $(30 \mu \mathrm{g})$, cefazolin $(30 \mu \mathrm{g})$, chloramphenicol $(30 \mu \mathrm{g})$, doxycycline $(10 \mu \mathrm{g})$, erythromycin $(15 \mu \mathrm{g})$, gentamicin $(10 \mu \mathrm{g})$, kanamycin $(30 \mu \mathrm{g})$, lincomycin $(15 \mu \mathrm{g})$, nalidixic acid $(30 \mu \mathrm{g})$, neomycin $(30 \mu \mathrm{g})$, ofloxacin $(5 \mu \mathrm{g})$, oleandomycin $(15 \mu \mathrm{g})$, oxacillin $(10 \mu \mathrm{g})$, polymixin $(300 \mathrm{U})$, rifampicin $(5 \mu \mathrm{g})$, streptomy- 
Table 1. Fatty acid profiles of species of the genus Gramella

Strains: 1, KMM 6048 ${ }^{\mathrm{T}}$; 2, G. echinicola $\mathrm{KMM} 6050^{\mathrm{T}}$; 3, G. portivictoriae UST040801-001 ${ }^{\mathrm{T}}$. Data from Lau et al. (2005), Nedashkovskaya et al. (2005) and this study. All strains were grown on marine agar 2216 for $48 \mathrm{~h}$. Strain $\mathrm{KMM} 6048^{\mathrm{T}}$ and G. echinicola $\mathrm{KMM} 6050^{\mathrm{T}}$ were grown at $25^{\circ} \mathrm{C}$, whereas $\mathrm{G}$. portivictoriae UST040801-001 ${ }^{\mathrm{T}}$ was grown at $30{ }^{\circ} \mathrm{C}$. Fatty acids amounting to $<1 \%$ of the total fatty acids in all strains are not shown. ND, Not detected; tr, trace $(<1 \%)$.

\begin{tabular}{|lccc|}
\hline Fatty acid & $\mathbf{1}$ & $\mathbf{2}$ & $\mathbf{3}$ \\
\hline iso- $\mathrm{C}_{14: 0}$ & $\mathrm{tr}$ & 1.4 & $\operatorname{tr}$ \\
$\mathrm{C}_{15: 0}$ & 3.9 & 7.1 & $\mathrm{ND}$ \\
$\mathrm{C}_{15: 1} \omega 6 c$ & 1.1 & 1.9 & 1.8 \\
anteiso- $\mathrm{C}_{15: 0}$ & 8.6 & 7.6 & 6.2 \\
iso- $\mathrm{C}_{15: 0}$ & 17.9 & 14.4 & 38.1 \\
iso- $\mathrm{C}_{15: 1} \mathrm{G}$ & 2.1 & 1.2 & $\mathrm{ND}$ \\
iso- $\mathrm{C}_{16: 0}$ & 6.3 & 13.1 & 1.9 \\
iso- $\mathrm{C}_{16: 1} \mathrm{G}$ & 2.7 & 5.8 & $\mathrm{ND}$ \\
$\mathrm{C}_{15: 0} 2-\mathrm{OH}$ & 2.8 & 2.0 & 1.0 \\
$\mathrm{C}_{15: 0} 3-\mathrm{OH}$ & $\mathrm{ND}$ & $\mathrm{ND}$ & 2.5 \\
iso- $\mathrm{C}_{15: 0} 3-\mathrm{OH}$ & 1.5 & 1.3 & 6.2 \\
iso- $\mathrm{C}_{16: 0} 3-\mathrm{OH}$ & 3.9 & 5.9 & 3.4 \\
$\mathrm{C}_{17: 0} 2-\mathrm{OH}$ & 5.1 & 2.6 & 1.5 \\
$\mathrm{C}_{17: 1} \omega 6 c$ & 3.6 & 3.6 & 1.7 \\
anteiso- $\mathrm{C}_{17}: 1 \omega 9 c$ & 2.2 & 2.0 & $\mathrm{ND}$ \\
iso- $\mathrm{C}_{17: 1} \omega 9 c$ & 5.5 & 3.5 & 5.7 \\
iso- $\mathrm{C}_{17: 0} 3-\mathrm{OH}$ & 12.4 & 6.7 & 11.2 \\
$\mathrm{C}_{18: 1} \omega 5 c$ & $\operatorname{tr}$ & $\mathrm{ND}$ & 1.0 \\
Summed feature $3 *$ & 11.6 & 11.4 & 8.8 \\
& & & \\
\hline
\end{tabular}

${ }^{*}$ Summed feature 3 comprises iso- $\mathrm{C}_{15: 0} 2-\mathrm{OH}$ and/or $\mathrm{C}_{16: 1} \omega 7 c$ that could not be separated by the Microbial Identification System.

cin $(30 \mu \mathrm{g})$, tetracycline $(30 \mu \mathrm{g})$ and vancomycin $(30 \mu \mathrm{g})$ (Research Center of Pharmacotherapy, Russia). Gliding motility was determined as described by Bowman (2000).

In accordance with the two other recognized species of the genus Gramella, strain KMM $6048^{\mathrm{T}}$ was heterotrophic, strictly aerobic, yellow-orange-pigmented and motile by gliding. It was oxidase-, catalase- and alkaline phosphatasepositive, required $\mathrm{NaCl}$ or seawater for growth, hydrolysed aesculin, gelatin and starch, and utilized carbohydrates. However, strain KMM $6048^{\mathrm{T}}$ differed from the type strains of the two other species of the genus in a number of phenotypic properties (Table 2).

Consequently, phylogenetic distinctiveness and differential phenotypic characteristics warrant description of strain KMM $6048^{\mathrm{T}}$ as a representative of a novel species in the genus Gramella, for which the name Gramella marina sp. nov. is proposed.

\section{Description of Gramella marina sp. nov.}

Gramella marina (ma.ri'na. L. fem. adj. marina of the sea, marine, a bacterium isolated from a marine environment).
Table 2. Phenotypic characteristics that differentiate strain KMM $6048^{\top}$ from other species of the genus Gramella

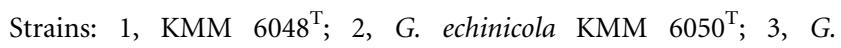
portivictoriae UST040801-001 ${ }^{\mathrm{T}}$. All strains were positive for the following tests: respiratory metabolism; gliding motility; oxidase and catalase activities; requirement for $\mathrm{Na}^{+}$ions for growth; growth with $1-6 \% \mathrm{NaCl}$ and at $4-36{ }^{\circ} \mathrm{C}$; hydrolysis of aesculin, gelatin, starch, Tween 40 and Tween 80; utilization of arabinose, galactose, glucose and sucrose; acid phosphatase, alkaline phosphatase, $\alpha$-chymotrypsin, cystine arylamidase, leucine arylamidase, valine arylamidase, esterase (C4), esterase lipase (C8), lipase (C14), $\alpha$-galactosidase, $\alpha$-glucosidase, $\beta$-glucosidase, trypsin and naphthol-AS-BI-phosphohydrolase activities; susceptibility to ampicillin, benzylpenicillin, chloramphenicol and tetracycline; and resistance to kanamycin. All strains were negative for the following tests: production of flexirubin-type pigments; nitrate reduction; $\alpha$-fucosidase and urease activities; $\mathrm{H}_{2} \mathrm{~S}$ and indole production; hydrolysis of agar, cellulose (CM-cellulose and filter paper) and chitin; acid production from fucose, lactose, rhamnose, sorbose, cellobiose, xylose, glycerol, adonitol, inositol, mannitol, sorbitol and citrate; and utilization of lactose, inositol and malonate. Data are from Lau et al. (2005), Nedashkovskaya et al. (2005) and this study. ND, Not determined.

\begin{tabular}{|c|c|c|c|}
\hline Characteristic & 1 & 2 & 3 \\
\hline Acetoin production & + & - & + \\
\hline Growth with $15 \% \mathrm{NaCl}$ & + & + & - \\
\hline \multicolumn{4}{|l|}{ Hydrolysis of: } \\
\hline Casein & + & + & - \\
\hline DNA & - & + & - \\
\hline Tween 20 & + & - & + \\
\hline \multicolumn{4}{|l|}{ Acid production from: } \\
\hline Arabinose, melibiose & + & - & - \\
\hline $\begin{array}{l}\text { Galactose, glucose, maltose, sucrose, } \\
\text { trehalose, raffinose }\end{array}$ & + & + & - \\
\hline$N$-Acetylglucosamine & - & + & - \\
\hline \multicolumn{4}{|l|}{ Utilization of: } \\
\hline $\begin{array}{l}\text { Acetic acid, L-asparagine, glycyl-L- } \\
\text { aspartic acid, L-threonine }\end{array}$ & - & + & - \\
\hline D-Galacturonic acid & + & - & - \\
\hline$\gamma$-Hydroxybutyric acid & - & - & + \\
\hline $\begin{array}{l}\alpha \text {-Ketoglutaric acid, L-alanine, L-alanyl- } \\
\text { glycine, L-glutamic acid, L-proline }\end{array}$ & + & + & - \\
\hline Melibiose & + & - & + \\
\hline Mannitol, sorbitol & - & - & + \\
\hline$N$-Acetylglucosamine & + & + & - \\
\hline Citrate & + & - & - \\
\hline \multicolumn{4}{|l|}{ Enzyme activities: } \\
\hline$\beta$-Galactosidase & + & + & - \\
\hline$\beta$-Glucuronidase, $N$-acetylglucosaminidase & - & + & - \\
\hline$\alpha$-Mannosidase & + & - & - \\
\hline \multicolumn{4}{|l|}{ Susceptibility to: } \\
\hline Streptomycin & + & - & - \\
\hline Vancomycin & + & - & ND \\
\hline DNA G $+C$ content $(\mathrm{mol} \%)$ & 40.0 & 39.6 & 39.9 \\
\hline
\end{tabular}

The main characteristics are the same as those given for the genus. In addition, cells are $0.4-0.6 \mu \mathrm{m}$ in width and 1.7$2.5 \mu \mathrm{m}$ in length. On marine agar, colonies are $2-3 \mathrm{~mm}$ in 
diameter, circular, shiny with entire edges and yelloworange-pigmented. Growth is observed at $4-37{ }^{\circ} \mathrm{C}$ (optimum, $28-30{ }^{\circ} \mathrm{C}$ ) and with $1-15 \%$ (w/v) $\mathrm{NaCl}$ (optimum, $2-5 \% \mathrm{NaCl}$ ). Arginine dihydrolase, lysine decarboxylase, ornithine decarboxylase and tryptophan deaminase activities are absent. Acid is produced from amygdalin, but not from cellobiose. D-Mannose, adipate, gluconate, malate and phenylacetate are utilized, but caprate is not. The substrates utilized in the GN2 MicroPlate are listed in Table 1. Susceptible to ampicillin, benzylpenicillin, carbenicillin, cefalexin, cefazolin, chloramphenicol, doxycycline, erythromycin, lincomycin, nalidixic acid, ofloxacin, oleandomycin, streptomycin, tetracycline, rifampicin and vancomycin, but resistant to gentamicin, kanamycin, neomycin, oxacillin and polymyxin. Other biochemical and physiological properties are shown in Table 2. The predominant fatty acids (i.e. $>5 \%$ of the total fatty acids) are iso- $\mathrm{C}_{15: 0}$, iso- $\mathrm{C}_{17: 0} 3-\mathrm{OH}$, anteiso- $\mathrm{C}_{15: 0}$, iso- $\mathrm{C}_{16: 0}$, iso- $\mathrm{C}_{17: 1} \omega 9 \mathrm{c}$ and summed feature 3 (comprising $\mathrm{C}_{16: 1} \omega 7 c$ and/or iso- $\mathrm{C}_{15: 0} 2-\mathrm{OH}$ and $\mathrm{C}_{17: 0}$ $2-\mathrm{OH})$.

The type strain is $\mathrm{KMM} 6048^{\mathrm{T}}\left(=\mathrm{KCTC} 12366^{\mathrm{T}}=\mathrm{LMG}\right.$ $25418^{\mathrm{T}}$ ), isolated from the sea urchin Strongylocentrotus intermedius collected in Troitsa Bay, Gulf of Peter the Great, Sea of Japan (also known as the East Sea). The DNA $\mathrm{G}+\mathrm{C}$ content of the type strain is $40.0 \mathrm{~mol} \%$.

\section{Acknowledgements}

This research was supported by grants from the Far-Eastern Branch of the Russian Academy of Sciences no. 09-III-A-06-228, Presidium of the Russian Academy of Sciences 'Molecular and Cell Biology' and State Contract 02.518.11.7169 from the Federal Agency for Science and Innovations of the Russian Federation. K. S. B. also acknowledges support from the KRIBB initiative program.

\section{References}

Bernardet, J.-F., Nakagawa, Y. \& Holmes, B. (2002). Proposed minimal standards for describing new taxa of the family Flavobacteriaceae and emended description of the family. Int J Syst Evol Microbiol 52, 1049-1070.

Bowman, J. P. (2000). Description of Cellulophaga algicola sp. nov., isolated from the surfaces of Antarctic algae, and reclassification of
Cytophaga uliginosa (ZoBell and Upham 1944) Reichenbach 1989 as Cellulophaga uliginosa comb. nov. Int J Syst Evol Microbiol 50, 18611868.

Felsenstein, J. (1993). PHYLIP (phylogenetic inference package), version 3.5c. Distributed by the author. Department of Genome Sciences, University of Washington, Seattle, USA.

Jukes, T. H. \& Cantor, C. R. (1969). Evolution of protein molecules. In Mammalian Protein Metabolism, vol. 3, pp. 21-132. Edited by H. N. Munro. New York: Academic Press.

Kim, S. B., Falconer, C., Williams, E. \& Goodfellow, M. (1998). Streptomyces thermocarboxydovorans sp. nov. and Streptomyces thermocarboxydus sp. nov., two moderately thermophilic carboxydotrophic species isolated from soil. Int J Syst Bacteriol 48, 59-68.

Lau, S. C. K., Tsoi, M. M. Y., Li, X., Plakhotnikova, I., Dobretsov, S., Wong, P. K. \& Qian, P. Y. (2005). Gramella portivictoriae sp. nov., a novel member of the family Flavobacteriaceae isolated from marine sediment. Int J Syst Evol Microbiol 55, 2497-2500.

Marmur, J. (1961). A procedure for the isolation of deoxyribonucleic acid from microorganisms. J Mol Biol 3, 208-218.

Marmur, J. \& Doty, P. (1962). Determination of the base composition of deoxyribonucleic acid from its thermal denaturation temperature. J Mol Biol 5, 109-118.

Minnikin, D. E., O’Donnell, A. G., Goodfellow, M., Alderson, G., Athalye, M., Schaal, A. \& Parlett, J. H. (1984). An integrated procedure for the extraction of bacterial isoprenoid quinones and polar lipids. J Microbiol Methods 2, 233-241.

Nedashkovskaya, O. I., Suzuki, M., Vysotskii, M. V. \& Mikhailov, V. V. (2003a). Reichenbachia agariperforans gen. nov., sp. nov., a novel marine bacterium in the phylum Cytophaga-FlavobacteriumBacteroides. Int J Syst Evol Microbiol 53, 81-85.

Nedashkovskaya, O. I., Kim, S. B., Han, S. K., Lysenko, A. M., Rohde, M., Zhukova, N. V., Falsen, E., Frolova, G. M., Mikhailov, V. V. \& Bae, K. S. (2003b). Mesonia algae gen. nov., sp. nov., a novel marine bacterium of the family Flavobacteriaceae isolated from the green alga Acrosiphonia sonderi (Kütz) Kornm. Int J Syst Evol Microbiol 53, 1967-1971.

Nedashkovskaya, O. I., Kim, S. B., Lysenko, A. M., Frolova, G. M., Mikhailov, V. V., Bae, K. S., Lee, D. H. \& Kim, I. S. (2005). Gramella echinicola gen. nov., sp. nov., a novel halophilic bacterium of the family Flavobacteriaceae isolated from the sea urchin Strongylocentrotus intermedius. Int J Syst Evol Microbiol 55, 391-394.

Saitou, N. \& Nei, M. (1987). The neighbor-joining method: a new method for reconstructing phylogenetic trees. Mol Biol Evol 4, 406425.

Stackebrandt, E. \& Ebers, J. (2006). Taxonomic parameters revisited: tarnished gold standards. Microbiol Today 33, 152-155. 